\title{
Sutan Sjahrir's Character Education Values in Indonesian Historical Records
}

\author{
Ari Yuda Kusuma1, Aman² \\ ${ }^{1,2}$ Universitas Negeri Yogyakarta, Indonesia \\ Ariyuda.2019@student.uny.ac.id
}

\begin{abstract}
A dignified national generation can be formed by instilling the values of character education. Value is a normative standard that influences humans in determining their choices. One of the figures who has the value of character education and has a big influence in Indonesia is Sutan Sjahrir as one of the founding fathers of the Nation. The purpose of writing this paper is to find out the values of character education contained in Sutan Sjahrir as one of Indonesia's heroes based on his existence in Indonesia's historical records. The method used in this writing is library research. Library research or library research is a research method that utilizes library sources to obtain research data. Data analysis includes four components, namely data collection, data reduction, data display, and data verification or conclusion drawing. The basic character values possessed by Sutan Sjahrir include religion, tolerance, democracy, hard work, responsibility, creative, independent, communicative and fond of reading. Sutan Sjahrir's character education values for the nation \& state are related to those stated, including patriotism, love for the country, self-sacrifice, nationalism, and social care. These values are very useful in shaping character to create the next generation who has a social spirit and become the pride of the family, nation and state. Tolerance, democracy, hard work, responsibility, creative, independent, communicative and fond of reading. Sutan Sjahrir's character education values for the nation \& state are related to those stated, including patriotism, love for the country, self-sacrifice, nationalism, and social care. These values are very useful in shaping character to create the next generation who has a social spirit and become the pride of the family, nation and state. tolerance, democracy, hard work, responsibility, creative, independent, communicative and fond of reading. Sutan Sjahrir's character education values for the nation \& state are related to those stated, including patriotism, love for the country, self-sacrifice, nationalism, and social care. These values are very useful in shaping character to create the next generation who has a social spirit and become the pride of the family, nation and state.
\end{abstract}

Keywords values of character education; Sutan Sjahrir; Indonesian historical records

\section{Introduction}

A dignified national generation can be formed by instilling the values of character education. Character is a picture of behavior in a person's daily habits concerning that it good or bad. In this case, the environment greatly influences the formation of one's character education (Purba, 2020). Value is a normative standard that influences humans in 
determining their choices. One of the figures who has the value of character education and has a big influence in Indonesia is Sutan Sjahrir as one of the founding fathers of the Nation. Sutan Sjahrir He was born in Padang Panjang, West Sumatra on March 5, 1909. Sutan Sjahrir came from a Minangkabau family who was quite respected and respected in Koto Gedang. West Sumatra. Since childhood, Soetan Sjahrir has enjoyed a stable economy and a modern family life. Sjahrir was the same brother as Rohana Kudus, a prominent female activist and journalist (Ikranegara, 2010. 79). Sjahrir married Poppy Saleh in 1950.

Sutan Sjahrir carried out his struggle for Indonesian independence through political diplomacy. Sjahrir's struggle to protect diplomacy made him the first person to speak at the United Nations when the Dutch launched their first Military Action in 1947, as a result of Sjahrir's stunning speech, the Dutch military action was condemned by the international community as an unacceptable act because the Netherlands had violated the agreement that had been made ( Romandhon, 2015: 212).

According to Gaol (2020) character is a trait attached to a person who is related to the creator, himself, his family, and the people around him including the wider community. One of the forms of national character is marked by the formation of the character of its. If people have good character, the nation will also have a good character. Character formation can be taught from an early age through the most basic education (Septiadi, 2019). By describing the values of character education found in Sutan Sjahrir as one of Indonesia's heroes based on his existence in Indonesia's historical records, it is hoped that he will be able to inspire the younger generation about the importance of character education then apply it to themselves, the environment, the nation and the country.

\section{Research Methods}

\subsection{Type of Writing}

The method used in this writing is library research. Zed (2008: 1) says that library research is a research method that utilizes library sources with the addition of other literature sources such as journals. This method was chosen because it is in accordance with the research objectives to describe the values of character education in the character Sutan Sjahrir.

\subsection{Data Collection Technique}

The data collection technique was carried out through literature studies. Literature study is the author obtains data from various sources such as reference books, research results and Internet media. Relevant sources are processed into descriptive analysis of data that produce conclusions and suggestions.

\subsection{Data Analysis}

Data analysis in qualitative writing was carried out after data collection took place. In writing this paper, the author uses an interactive analysis model as proposed by Miles and Habermen, which includes four components, namely data collection, data reduction, data display, and data verification or conclusion drawing (Sugiyono, 2019: 438-439). In writing this paper, a data reduction process was carried out through the process of selecting and centralizing language regarding the values of character education in the character Sutan Sjahrir. Furthermore, data analysis was carried out on the data that had been obtained until a conclusion was obtained about the values of Sutan Sjahrir's Character Education. 


\section{Discussion}

\subsection{Biography of Sultan Sjahrir}

Sutan Sjahrir was born to Mohammad Rasad and Poetri Siti Rabiyah in Padang Panjang, West Sumatra on March 5, 1909. (Ikranegara. 2010: 79). Sjahrir married Poppy Saleh in 1950. From the marriage of Sjahrir and Poppy they were blessed with two children, the first named Kriya Asjah who was born in 1957 and the second named Siti Rabyah Paryati who was born in 1960 (Tempo, 2010: 150). Sutan Sjahrir's childhood was spent at the Europeesche Lagere School (ELS), this school is at the same level as elementary school. Then Sjahrir continued his studies at Meer Uitgebreid Lager Onderwijs (MULO), a Dutchspeaking Junior High School, in Medan (Maulana 2014: 31). One year from 1926 to 1929, then Sjahrir continued his education at Algemenei Middelbare School (AMS) majoring in Westers Klassieke Afdeling (majoring in Classical Western Culture), Bandung. After graduating from AMS, Sjahrir left for the Netherlands, to continue his education at the Faculty of Law, University of Amsterdam, the Netherlands (Romandhon, 2015: 170). Sutan Sjahrir is the main founding figure of the Indonesian Socialist Party who provided many forms of political thought with the formulation and achievements of the Indonesian nation in 1945-1965 (Syahira 2012: 33).

Together with Hatta in 1929 Sjahrir joined the Indonesian Association (Pl). Early in 1930 Sjahrir was also active in the Indonesian National Party (PNI) which later changed to the Indonesian National Education (PNI-Baru). In 1942 when the Sjahrir movement became a figure in the underground movement. In 1945, Sjahrir was chosen as the first Prime Minister of Indonesia with a cabinet term that lasted for 3 periods, namely Sjahrir Cabinet I for the period of November 14, 1945 to March 12, 1946, Sjahrir Cabinet II for the period March 13, 1946 to October 2, 1946, and Cabinet Sjahrir III period 2. October 1946 to 27 June 1947 (Santoso, 2014: 29). On the morning of April 15, 1966.

\subsection{Character Education Values}

Value comes from the Latin word vale're which means useful, able to be, empowered, applicable, so that value is defined as something that is considered good, useful, and most correct according to the belief of a person or group of people, value is also a quality of something that makes it liked, wanted, pursued, valued, useful and can make people who live it to be dignified (Adisusilo, 2013: 56). Characters are universal values of human life behavior which include all life activities, whether related to God, oneself, fellow humans, or with the environment which are manifested in thoughts, attitudes, words, and actions based on religious norms, laws, and regulations. manners, culture, and customs (Suyadi 2013: 5).

From some of the above discussions it can be concluded that character education is the behavior of humans with their lovers, themselves, together with humans and their environment based on the inherent nature of a person so that it is reflected in patterns of thought and behavior patterns in responding to situations morally which are then actualized through potential action from within and internalization of values including:

According to Wibowo (2013: 14), there are eighteen national cultural characters,

Table 1. The Eighteen National Cultural Characters

\begin{tabular}{|c|c|c|}
\hline $\begin{array}{c}\text { No } \\
\cdot\end{array}$ & Score & Description \\
\hline 1 & Religious & Attitudes and behaviors that are obedient in carrying out \\
\hline
\end{tabular}




\begin{tabular}{|c|c|c|}
\hline & & $\begin{array}{l}\text { the teachings of their religion, are tolerant of the } \\
\text { implementation of the worship of other religions, and } \\
\text { live in harmony with adherents of other religions. }\end{array}$ \\
\hline 2 & Honest & $\begin{array}{l}\text { Behavior based on efforts to make himself a person who } \\
\text { can always be trusted in words, actions and work. }\end{array}$ \\
\hline 3 & Tolerant & $\begin{array}{l}\text { Attitudes and actions that appreciate differences in } \\
\text { religion, ethnicity, opinion, attitudes and actions of } \\
\text { others who are different from oneself }\end{array}$ \\
\hline 4 & Discipline & $\begin{array}{l}\text { Actions that show orderly behavior and comply with } \\
\text { various rules and regulations. }\end{array}$ \\
\hline 5 & Hard work & $\begin{array}{l}\text { Behavior that shows a genuine effort to overcome } \\
\text { various obstacles to learning and assignments, and to } \\
\text { complete tasks as well as possible. }\end{array}$ \\
\hline 6 & Crea & $\begin{array}{l}\text { Thinking and doing something to produce a new way or } \\
\text { result from something that is already owned. }\end{array}$ \\
\hline 7 & Indep & $\begin{array}{l}\text { Attitudes and behaviors that are not easily dependent on } \\
\text { other people to complete tasks. }\end{array}$ \\
\hline 8 & Demc & $\begin{array}{l}\text { A way of thinking, behaving, and acting that values the } \\
\text { rights and obligations of oneself and others. }\end{array}$ \\
\hline 9 & Curiosity & $\begin{array}{l}\text { Attitudes and actions that always seek to know more } \\
\text { deeply and broadly from something they have learned, } \\
\text { seen, and heard. }\end{array}$ \\
\hline 10 & \begin{tabular}{ll|} 
Spirit & of \\
nationality &
\end{tabular} & $\begin{array}{l}\text { A way of thinking, acting, and having an insight that } \\
\text { places the interests of the nation and state above the } \\
\text { interests of themselves and their groups. }\end{array}$ \\
\hline 11 & $\begin{array}{l}\text { Love the } \\
\text { Motherland }\end{array}$ & $\begin{array}{l}\text { A way of thinking, behaving, and acting that shows } \\
\text { loyalty, concern and high respect for language, the } \\
\text { physical, social, cultural, economic and political } \\
\text { environment of the nation. }\end{array}$ \\
\hline 12 & $\begin{array}{l}\text { Appreciate } \\
\text { achievements }\end{array}$ & $\begin{array}{l}\text { Attitudes and actions that encourage him to produce } \\
\text { something useful for society, acknowledge and respect } \\
\text { the success of others. }\end{array}$ \\
\hline 13 & unicati & $\begin{array}{l}\text { Actions that show enjoyment of talking, associating, and } \\
\text { cooperating with others. }\end{array}$ \\
\hline 14 & Love peace & $\begin{array}{l}\text { Attitudes, words, and actions that cause other people to } \\
\text { feel happy and secure in their presence. }\end{array}$ \\
\hline 15 & Like to read & $\begin{array}{l}\text { The habit of providing time to read various readings that } \\
\text { are good for him. }\end{array}$ \\
\hline 16 & $\begin{array}{l}\text { Environment } \\
\text { al care }\end{array}$ & $\begin{array}{l}\text { Attitudes and actions that always try to prevent damage } \\
\text { to the natural environment and its surroundings. }\end{array}$ \\
\hline 17 & Social care & $\begin{array}{l}\text { Attitudes and actions that always want to provide } \\
\text { assistance to others and society in need. }\end{array}$ \\
\hline 18 & Responsible & $\begin{array}{l}\text { Attitudes and behavior of a person to carry out their } \\
\text { duties and obligations. }\end{array}$ \\
\hline
\end{tabular}




\subsection{Basic Character Education of Sutan Shajrir a. Religious}

Sjahrir has a religious character, seen from his childhood that Sjahrir not only received formal education, he also received religious education. In the morning Sjahrir studied at a formal school, then in the afternoon he studied the Koran, Sjahrir also received religious knowledge from his father. He received religious education with this formal education up to ELS. This education is what makes Sjahrir equipped in his life journey (Romandhon. 2015: 170). When engaged in politics, Sjahrir always adhered to the first principle of Pancasila so that there were no difficulties for him in the world of politics, he had the belief that whoever truly believes in God Almighty there is no difficulty for him (Anwar, 2010: 173).

\section{b. Tolerance}

Sjahrir's attitude of tolerance was shown during his exile by illustrating that all the population, be it Javanese, Minangkabau, Banten, Sundanese and others were part of the Indonesian nation, Sjahrir gave the impression he got from the exiles here that they were part of the Indonesian nation, meaning Javanese, Minangkabau, Banten, or Sundanese, if we want to understand them then approach them (Sjahrir. 1990: 82). Sjahrir mingled with all circles of the population, both Muslim, Chinese, Arab and Indo-Dutch (Mrazk, 1996: 363).

\section{c. Democracy}

Sjahrir acknowledged that there were basic rights such as freedom of speech, assembly and association as the leader of the underground movement. Sjahrir was diligent in holding discussions. According to Des, apart from in his own house, Sjahrir often had discussions in the Manggarai area, Jakarta. If not in Manggarai, the discussion will be held in Sindanglaya, Cipanas, which is the home of Halim, one of Sjahrir's close relatives. Participants who were often invited to discuss were St. Takdir Alisjahbana, Amir Hamzah, Mr. Soejitno, Dr. Soedarsono, Zainal Abidin, Hamdani, and Dr. Toha. (Santoso, 2014: 89).

\section{d. Hard Work}

The result of Sjahrir's hard work made Sjahrir the first person to speak at the United Nations when the Netherlands launched its first Military Action in 1947, as a result of Sjahrir's stunning speech, the Dutch military action was condemned by the international community as an unacceptable action because the Netherlands had violated the agreement that had been made. (Romandhon, 2015: 212). The peak of Sjahrir's success in the field of diplomacy was the achievement of the Linggarjati Agreement, which showed that Indonesia could reclaim colonies controlled by the Dutch (Anwar, 2010: 207).

\section{e. Responsible}

Sjahrir's courageous character was shown by taking risks for his actions. It was proven in a meeting that Bung Karno was involved in a debate, until Bung Karno shouted at Suwarni in Dutch. As the leader of the meeting, Sjahrir's hammer quickly knocked on the table, while warning Bung Karno in the national meeting not to use Dutch and not to say harsh words during the meeting (Anwar, 2010: 62).

Sjahrir is known as a young man who likes politics and does not hesitate to criticize the Dutch colonial government, even though he received a warning from his desert (a Dutch teacher), he is very good at defending his opinion (Anwar, 2010: 161). Because humans face the world in which they are at the same time bear responsibility for themselves and the future of their world (Fidaus 2011: 267). 


\section{f. Creative}

The fact that Sjahrir has a creative character is that when Sjahrir became an exile in Digul, it did not make Sjahrir discouraged. In Digul with Hatta, Sjahrir used his days to give courses to all prisoners. The courses provided are in the form of philosophy, politics, history and economics (Romandhon, 2015: 199). Apart from teaching courses to prisoners, Sjahrir also taught writing, historical mathematics and sewing to his adopted children Does, Des, Lily, Mimi and even Sjahrir rented a Singer sewing machine and subscribed to fashion magazines to find samples of girls' clothes (Santoso, 2014: 79).

For Sjahrir, nothing felt heavy or troublesome for all subjects, for him everything went smoothly, even though we know Sjahrir never prepared lessons at night for the next day at school but when called by his teacher he was always able to answer questions given by his teacher (Anwar, 2010: 90).

\section{g. Independent}

When Sjahrir was chairing a meeting in Solo, the electricity suddenly went out. Meanwhile, a gunshot was heard outside the building. The meeting participants who were already sitting up and down ran for protection. Not long after, the electricity came back on. Apparently, nothing happened. The meeting participants returned to their seats. Only Sjahrir did not run away, he sat quietly, this made the meeting participants amazed (Anwar, Rosihan. 2010: 61).

\section{h. Communicative}

The fact that Sjahrir is a communicative person is shown by making friends with other people. Sjahrir has a sympathetic appearance, is smiling, one thing that makes him a lot of friends is his intelligence and sharpness of mind and is easy to analyze the content and meaning of the questions he sees or hears (Anwar, 2010: 61). Although Sjahrir is known to be intelligent, broad-minded and likes to read books, he is not a student who only keeps himself busy with textbooks and his personal work (Santoso, 2014: 21).

Sjahrir's extensive association with intellectuals and political activists in Leiden has left its mark until now, his name is written as the name of the street, namely Sjahrirstraat (Tempo, 2010: 21). Sjahrir also mingled with youths at that time, such as Affandi, Baharoeddin, and Chairil Anwar, who later gave him a painting that still hung in his residence, Chairil Anwar, who became a legend for the entire revolutionary generation of 45 , was considered by Sjahrir as his protégé ( Mrazek, 1996: 534).

\section{i. Like to Read}

Sjahrir has a private library at his house which is located at Javaweg 61, Jakarta which is now called HOS Cokroaminoto, not too many but what is clear is that books are often used arranged on shelves such as a collection of works by the Dutch poet, Hendrik Marsman, various other anthologies about Dutch poetry from the century. the 20th, novels by Beb Vyuk, The Dutch Encyclopedia, several reference books and brochures on Italian, English and European socialism generally, books in Dutch, English and German mostly published in the late 1940s and early 1950s -an (Mrazek, 1996: 737). At night, Sjahrir felt calm when he read the biography of Engels by Gustav Mayer (Sjahrir, 1990: 118).

\subsection{The values of Sultan Sjahrir's Character Education for the Nation and State a. Patriotism}

Sjahrir's patriotism was seen when he pointed out the reasons for the vacuum of power: first, those who took the reins of government were those with weak souls who used to bow 
and run for Japan and the Netherlands. Second, there is a feeling that independence is a gift from Japan. Third, youths do not have the requirements to lead, because they only have the skills to become soldiers, receive orders and are not taught the spirit of leadership (Tempo, 2010: 197). For this reason, Sjahrir was determined not to give up on nationalist-cultural politics, and this politics had to be thrown away from the minds of the Indonesians.

On August 14, 1947, Sjahrir addressed the UN Security Council session in front of representatives of the nations of the world. He said that Indonesia as a nation had a civilization which was then exploited by the colonialists. In his speech, Sjahrir also broke one by one the arguments about the Indonesian-Dutch dispute which were conveyed by the Dutch representative Van Kleffens. The impact of Sjahrir's speech before the UN Security Council session Indonesia succeeded in fighting for and seizing its position as a sovereign nation that was recognized in the international world. (Santoso, 2014: 146). 27

Sjahrir also sacrificed his body and soul to defend the truth, in fact this was shown to one of Sjahrir's services at that time, when he saved Soekarno-Hatta's position as President and Vice President, Sjahrir also fueled the people's fighting spirit from the threat of an allied court on accusations of being a Japanese collaborator. (Anwar, 2010: 414).

The value of patriotism in Sutan Sjahrir has influenced the future generations of the nation to foster and develop patriotism values for the Indonesian nation. The character of patriotism must be possessed by students in order to have a brave (assertive) attitude, be leadership, sacrifice body and soul, and have the awareness to do good.

\section{b. Love the Motherland}

Sjahrir's character who loves his homeland can be proven from his writings about his admiration for the beauty of Indonesia, especially the eastern part of Indonesia. When Sjahrir traveled to Sulawesi he told about the natural beauty of this area, such as the blue sea, white rocks, white beaches, behind which were green and blue mountains, with tribes that had their own uniqueness and various religions (Sjahrir, 1990:53).

Sjahrir understood the importance of independence, he was willing to experience suffering and sacrifice for Indonesia's independence from all forms of oppression (Anwar, 2010: 87). The struggle after independence for Sjahrir was a struggle to get the freedom of the soul of the Indonesian nation, no more wars, and enmity among the Indonesian people (Anwar, 2010: 285).

Sjahrir is a leader who likes to solve problems by means of diplomacy, for him guerrilla warfare carried out by the Indonesian people can be troublesome for the Dutch army, but the logical consequences of a war must be paid very dearly by the Indonesian people such as a family who lost their child during the war, or a child. who lost his father during the war. Sjahrir did not want the Indonesian people to be trapped in a fascist movement that upholds violence (Romandhon, 2015: 211).

Sjahrir's character of patriotism can be used as a guide or an example for the nation's future generations. The next generation of the nation must have a character of love for the country by having a character of love for the country, they will try with all their efforts to protect, safeguard their sovereignty, honor and everything that is owned by their country. This love for the country encourages individual behavior to build their country with full dedication. Therefore, the character of love for the country needs to be instilled in the soul of every successor of the nation who becomes a citizen of a country or nation so that the goal of living together can be achieved. 


\section{c. Willing to Sacrifice}

Hatta once said that Sjahrir fought for Indonesian independence, but suffered in exile even after Indonesian independence he was in prison on charges he never made. Sjahrir is one of the seven heroes of the Indonesian Revolution because he once urged Soekarno to proclaim independence even though he himself did not attend this historic event, and he chose an elegant way to drive out colonialism, namely through diplomacy (Santoso, 2014: 215).

Sjahrir had an important role for the independence of the Republic of Indonesia, at the end of his life he preferred the silent way. Soekarno arrested and imprisoned Sjahrir (19621965) without trial until he suffered a stroke. (Mrazek, 1996: 863). Sjahrir at the end of his life died as a political prisoner. Sjahrir's ideas are still alive after he passed away, even now his thoughts still inspire intellectual life in the country (Anwar, 2010:379).

Sjahrir, who has a self-sacrificing character, can be used as an example of character education that can be taught to the nation's future generations. The next generation of the nation must be instilled with a self-sacrificing character education which has been exemplified by heroes, one of which is Sjahrir, the nation's future generation must have a character of Willing to Sacrifice. Like the sincere, sincere, unyielding spirit of devotion that Sjahrir has.

\section{d. Social Care}

The character of Sjahrir's social concern can be seen when he is active in all fields of activity, he is actively raising funds for the construction of public schools that were established for the education of the common people. In addition, he frequently visits villages in Priangan, West Java and the area around his birthplace, Padang Panjang. This is done as material for reflection on how to improve education for the nation (Santoso, 2014: 20).

The character of Sjahrir's social care was seen as exiled, he still paid attention to his friends in exile, Sjahrir considered that he and his friends were victims of the conditions of the era that fought for Indonesian independence. If the Indonesian nation had not been colonized by the colonial government, perhaps Sjahrir and his friends would not have been in exile (Sjahrir, 1990: 125).

Paying attention to the distress of others is very important for everyone because one cannot live alone in this world. Likewise, the importance for future generations because one day they will live independently without their parents. By paying attention to the distress of others, they will be sociable and appreciated. The formation of a character of social care for future generations to create future generations who have a social spirit and become the pride of the family and the nation.

\section{e. Nationalism}

The character of nationalism possessed by Sjahrir can be seen through his view of independence, for Sjahrir independence is a path to ideals, Sjahrir considers that nationalism must submit to the interests of democracy. When nationalism was the furnace that roasted young people in the era of independence, Sjahrir came with an attitude of nationalism that was not narrow so that it could cool the situation at that time. For Sjahrir, true independence is the formation of space for the people to realize themselves, to bring out their talents in freedom without hindrance based on the laws in force at that time (Tempo, 2010: 199).

In fighting for Indonesian independence, Sjahrir used all his energies to face all challenges, especially in terms of the effects of demoralization, shortsightedness, mutual suspicion, and psychological deviations in his life of exile (Tempo, 2010: 34). Sjahrir's strong spirit of national ideology was seen when he mobilized his time to spread the news of the proclamation. Gambir Station is used as an arena for demonstrations. (Tempo, 2010: 66). 
Sjahrir's character of nationalism is reflected in Sjahrir's attitude of being a statesman, anti-colonialism, not wanting to be harassed by other nations, prioritizing the interests of the nation and the State, acting for the interests of the nation and having a strong national ideology. The character of nationalism is very important for the nation's future generations so that they have a sense of love for the nation's heroes, so that the nation's successors have a strong national ideology, make the nation's successors love their nation and teach the nation's successors to love their environment more and protect their environment. So that they can emulate Sjahrir's attitude of nationalism for the Indonesian nation.

\section{Conclusion}

Sutan Sjahrir is a hero whose existence was very influential in Indonesian history. Sutan Sjahrir, who is famous for his struggle for Indonesian independence through political diplomacy. Through diplomacy which became the stage for his struggle, Sjahrir educated all his thoughts and energies in fighting for and defending Indonesian independence. The existence of Sutan Sjahrir who has a strong character is seen in every action. Until the end of his life living in exile, Sjahrir still loved Indonesia as his homeland that he had fought for all his life.

By studying the values of character education possessed by the figure of Sutan Sjahrir, it is hoped that it will be able to inspire the younger generation and the general public. Because Sutan Sjahrir has fundamental values including, religious, tolerance, democracy, hard work, responsibility, creative, independent, communicative and likes to read. Sutan Sjahrir's character values for the nation \& state are related to those stated, including, patriotism, love for the country, willingness to sacrifice, nationalism, and social care. These values are very useful in shaping character for future generations to create future generations who have a social spirit and become the pride of the family, nation and state.

\section{References}

Anwar, Hamid. 2011. Metode Penelitian Pendidikan. Bandung : Alfabeta.

Damadi, Hamid. 2011. Metode Penelitian Pendidikan. Bandung: Alfabeta

Firdaus, M Yunus. Kebebasan dalam filsafat Eksistensialisme Jean Paul Sarte. 2011. Jurnal Al-Ulim :IAIN Ar-Raniry. Volume 11. Nomor 2. Desember 2011.

Gaol, R.L., and Sitepu, A. (2020). The Influence of Used Good-Based Learning Media on the Value of Chracter Education and Student's Motivation to Study. Budapest International Research and Critics in Linguistics and Education (BirLE) Journal Vol 3 (4): 16961703.

Ikranegara. 2010. Sejarah Lengkap Pahlawan Indonesia. Jakarta: Sandro Jaya.

Kemendiknas. 2010. Pengembangan Pendidikan Budaya dan Karakter Bangsa. Jakarta:Puskur-Balitbang

Maulana, Eko. 2014. Pemikiran Politik Sultan Sjahrir Tentang Revolusi. Jurnal Review Politik. Volume 4, Nomor 1, Juni 2014.

Mulyana, Rohman. 2011. Mengatikulasikan Pendidikan Nilai. Bandung: Alfabeta

Mrazek, Rudolf. 1996. Sjahrir Politik dan Pengasingan di Indonesia. Jakarta: Yayasan Obor Indonesia

Purba, A.R., Herlina, and Siahaan, J. (2020). Limbaga (Proverbs) Simalungun as a Source of Forming Character Education. Budapest International Research and Critics in Linguistics and Education (BirLE) Journal Vol 3 (3): 1623-1629. 
Rawantina. 2013. Penanaman Nilai Nasionalisme dan Patriotisme untuk Mewujudkan Pendidikan Karakter pada Mata Pelajaran Pendidikan Kewarganegaraan Siswa Kelas X SMA Negeri 4 Sidoarjo. Jurnal Kajian Moral dan Kewarganegaraan Vol. 1 No.1

Romandhon. 2015. Soekarno Hatta Sjahrir Kisah dan Memoar Tiga Macan Asia di Tengah Hiruk Pikuk Perjuangan. Yogyakarta: Araska

Santoso, Lukman. 2014. Sutan Sjahrir Pemikiran dan Kiprah Sang Pejuang Bangsa. Yogyakarta: Palapa

Septiadi, H. N., Andayani, and Wardani, N. E. (2019). Planting Base Value of Hardworking Character Education through Ulid Novel. Budapest International Research and Critics in Linguistics and Education (BirLE) Journal Vol 2 (3): 36-44.

Syahira. 2012. Pemikran Politik Sutan Sjahrir.Jurnal Politik. Volume 1. Nomor 2, Oktober 2012.

Sjahrir. 1990. Sutan Sjahrir Renungan dan Perjuangan. Jakarta: Penerbit Djambatan.

Sugiyono. (2019). Metode Penelitian Pendidikan. Bandung: Alfabeta

Surbayana. 2016. Building The Positive Self-Concept Through Patriotism. Jurnal Dinamika Pendidikan Dasar, Vol 8 No. 1.Hlm 31

Tempo. 2010. Peran Besar Bung Kecil. Jakarta: Gramedi

Wibowo, Agus. 2013. Manajemen Pendidikan Karakter di Sekolah. Yogyakarta: Pustaka Belajar

Zed, Mestika. 2008. Metode Penelitian Kepustakaan. Jakarta: Yayasan Obor. 